\title{
熱応カ・クリープ問題の感度解析*
}

\author{
陳献*1, 中 村 和 博*1 \\ 森昌 彦*1, 久田俊 明*2
}

\section{Sensitivity Analysis for Thermal Stress and Creep Problems}

\author{
Xian CHEN*3, Kazuhiro NAKAMURA, \\ Masahiko MORI and Toshiaki HISADA \\ ${ }^{* 3}$ Takasago R \& D Center, Mitsubishi Heavy Industries, Ltd., \\ 2-1-1, Shinhama Arai-cho, Takasago, Hyogo, 676-8686 Japan
}

\begin{abstract}
In this work, a finite element sensitivity analysis method for thermal stress and creep problems is proposed. The method is characterized by the so-called semi-analytical direct differentiation approach, i. e., the formulation is based on the direct differentiation but the variation of internal force due to the perturbation of design parameters is evaluated numerically. Since the corresponding subroutine of an existing finite element analysis code may be used, it is unnecessary to manipulate the adopted constitutive relation at sensitivity analysis stage. Thus, the proposed method can be applied for various temperature and time dependent problems. The effectiveness of the method is examined through a couple of numerical examples.
\end{abstract}

Key Words: Computational Mechanics, Finite Element Method, Nonlinear Problem, Thermal Stress, Creep, Sensitivity Analysis

\section{1. 粕 霎}

高温で運転する各種機器においては熱応力及びクリー プ現象が構造強度、信頼性に大きな影響を与えている。 しかし現象が複雑である為, 材料、構造寸法及び熱条 件などに関する設計の合理的改善，さらには最適設計 等を行うためには，設計変数の変動に対する構造応答 の変化率, 即ち感度を知ることが必要である。感度解 析法として最も直接的な方法は有限差分法(FDM: Finite Difference Method)である。これは設計変数を実 際に変動させた値を用いて有限要素解析を行い, 差分 法で感度を求める手法である。しかし当然のことなが ら多変数大規模非線形問題に対しては計算時間及びコ ストが膨大になるため，より効率的な感度解析法の研 究が多数行われている。特に構造挙動が变形履歴に依 存するような問題においては計算効率の観点から, 有

* 原稿受付 1999 年 1 月 18 日。

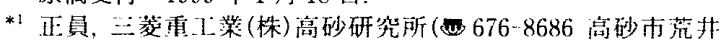
町新浜 2-1-1).

*2 正員, 東京大学大学院T:学系研究科(1130033 東京都文 宗区本郷 7-3-1).

E-mail : xchen@sml.k.u-tokyo.ac.jp
限要素解析の基礎式を設計変数に対して微分する直接 微分法(DDM:Direct Differentiation Method)が主流となっ ている。しかし弾塑性、クリープのような材料非線形 性を表す構成則が多様に提案されている現状では，定 式化が圥長になりがちな直接微分法を個別に適用する ことは現実的でなく，感度解析の普及のためには，よ り簡便かつ汎用的な手法が望まれる。

一方，著者らは直接微分法に基づく定式化において， 設計变数に対する内力や接触力の微分のみを差分的に 評価する半解析的直接微分法 (SDM:Semi-analytical Differentiation Method) を用いて大变形弾塑性問題(1), 無摩擦接触問題(2)の感度解析を行い, 良好な結果を得 てきた。本研究では熱ひずみ及びクリープひずみを考 慮し, 半解析的直接微分法による熱応力・クリープ問 題に対する感度解析法を提案する。この方法は反復計 算をせず有限要素解析と同時に感度を求めることがで きるほか，既存の有限要素解析システムの計算ルーチ ンを利用することにより，構成則の具体的な形式を意 識することなく実行可能であるため，効率性と沉用性 を併せ持つ手法である。

次節ではまず本問題における感度解析の定式化を行 い，第 3 節では数值解析例を通じて提案した手法の有 
効性を検証する。なお本研究では温度場は熱条件によ り決められ，構造変形による影警は無視できると仮定 する。

\section{2. 就応カ・クリープ䦓題の感度解析定式化}

\section{$2 \cdot 1$ 有限要素解析 変形前の配置を基準配置} とする total Lagrange 表記による仮想仕事式は次式で 与えられる。

$$
\int_{V} S: \delta E d V=\int_{S}^{\bar{t}} \cdot \delta \boldsymbol{u} d S+\int_{V} \rho_{0} \boldsymbol{g} \cdot \delta \boldsymbol{d u d V}
$$

ここで $V, S$ は物体の変形前の配置での体積領域及び 公称表面力 $\overline{\boldsymbol{t}}$ の作用する表面領域； $\rho_{0} g$ は単位体積 あたり物体力； $\boldsymbol{S}, \boldsymbol{E}$ は変形前の配置を基準とする第 2 Piola-Kirchhoff 応力と Green-Lagrange ひずみである。 上式の雨辺はそれぞれ内力及び外力による仮想仕事を 表している。さらに，uを变位，(·sをテンソルの対 称成分とし， $\nabla_{x}=\left(\partial / \partial X_{i}\right) e_{i}$ を用いて任意ベクトル $a$ $b$ に対するテンソル演算子 $e(a), \eta(a, b)$ を次のように 定義す机ば,

$$
\begin{aligned}
& \boldsymbol{e}(\boldsymbol{a}) \equiv\left(\boldsymbol{a} \otimes \nabla_{\boldsymbol{X}}+\left(\boldsymbol{a} \otimes \nabla_{\boldsymbol{X}}\right)^{T} \cdot\left(\boldsymbol{u} \otimes \nabla_{X}\right)\right)_{s} \\
& \boldsymbol{n}(\boldsymbol{a}, \boldsymbol{b}) \equiv\left(\left(\boldsymbol{a} \otimes \nabla_{X}\right)^{T} \cdot\left(\boldsymbol{b} \otimes \nabla_{X}\right)\right)_{s}
\end{aligned}
$$

関係式

$$
\begin{aligned}
& \delta E=e(\delta \boldsymbol{u}) \\
& \dot{E}=e(\dot{u}) \\
& (\delta E)^{\cdot}=(e(\delta u))^{\cdot}=\boldsymbol{\eta}(\delta u, \dot{u})
\end{aligned}
$$

が成り立つので，仮想仕事式及びその微分が次のよう に表せる。

$$
\begin{aligned}
& \int_{V} \boldsymbol{S}: \boldsymbol{e}(\boldsymbol{\delta u}) d V=\int_{S} \bar{t} \cdot \delta \boldsymbol{u} d S+\int_{V} \rho_{0} \boldsymbol{g} \cdot \delta \boldsymbol{u} d V \\
& \int_{V} \dot{\boldsymbol{S}}: \boldsymbol{e}(\boldsymbol{\delta u}) d V+\int_{V} \boldsymbol{S}: \boldsymbol{\eta}(\boldsymbol{\delta u}, \dot{\boldsymbol{u}}) d V \\
& =\int_{S} \dot{\overline{\boldsymbol{t}}} \cdot \delta \boldsymbol{u} d S+\int_{V} \rho_{0} \dot{\boldsymbol{g}} \cdot \delta \boldsymbol{u} d V
\end{aligned}
$$

微小変形における熱ひずみと、クリープひずみとをを 考慮した速度型構成則は次式で表すことができる(3)。

$$
\dot{\sigma}=D^{e p}:\left(\dot{\boldsymbol{\varepsilon}}-\dot{\boldsymbol{\varepsilon}}^{\prime}-\dot{\boldsymbol{\varepsilon}}\right)
$$

$D^{e p}$ は 4 階の弾塑性構成則テンソルであり，熱及びク リープひずみに関しては次の関係がある。

$$
\begin{aligned}
& \dot{\boldsymbol{\varepsilon}}=\alpha \dot{T} \\
& \dot{\boldsymbol{\varepsilon}}=\frac{3 \sigma}{2 \bar{\sigma}} \dot{\bar{\varepsilon}}
\end{aligned}
$$

$T$ は温度， $\alpha$ は線膨脹係数， $\boldsymbol{\sigma}^{\prime} ， \bar{\sigma} ， \dot{\bar{\varepsilon}}^{c}$ はそれぞれ 偏差応力及び Mises 型の相当応力, 相当ひずみ速度を 表す。テと㐫の関係は単軸状態における応力とクリー プひずみ速度の間の関係に一致するとしてさまざまな 提案があるが, 一般的に $\dot{\bar{\varepsilon}}^{\text {“ }}$ は応力、温度及び時間の 関数として表すことができる(4)。

$$
\dot{\bar{\varepsilon}}^{c}=f(\bar{\sigma}, T, t)
$$

大変形微小ひずみを仮定できる場合， $\boldsymbol{\sigma}$ と $\boldsymbol{\varepsilon} \boldsymbol{S}$ と $\boldsymbol{E}$ で置き換えることにより微小変形における構成則 が利用できること(5)から，

$$
\dot{\boldsymbol{S}}=D^{e p}:\left(\dot{\boldsymbol{E}}-\dot{\boldsymbol{E}}_{a}\right)
$$

が得られる。但し，

$$
\dot{\boldsymbol{E}}_{a}=\alpha \dot{T I}+\frac{3 S^{\prime}}{2 \bar{S}} f(\bar{S}, T, t)
$$

これにより熱・クリープ変形によるひずみを初期ひず みと見なすことで通常の大変形弾塑性解析法が適用で きる。

仮想仕事式 (7) について有限要素法における離散化 を行うと， $U$ を全体節点変位べクトル， $\Sigma$ を要素の 重ね合わせ， $B_{l}$ をを $e(\cdot)$ に対応する一種のひずみ・節 点変位マトリックス， $N$ を形状関数マトリックス， “^”をテンソル及びベクトルの成分からなる配列と して，仮想変位の任意性により，等価節点内力 $\boldsymbol{Q}$ と 外力 $\boldsymbol{F}$ の間の平衡方程式が次のように導かれる。

$$
Q=F
$$

但し,

$$
\begin{aligned}
& \boldsymbol{Q}=\sum_{e} \int_{V^{e}} \boldsymbol{B}_{l^{T}}^{T} \hat{\boldsymbol{S}} d V^{e} \\
& \boldsymbol{F}=\sum_{e} \int_{S^{*}} \boldsymbol{N}^{r} \hat{\bar{t}} d S^{e}+\sum_{e} \int_{V^{e}} \boldsymbol{N}^{T} \rho_{0} \hat{\boldsymbol{g}} d V^{e}
\end{aligned}
$$

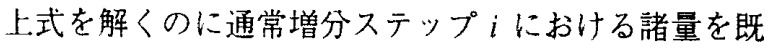
知としてステップ $i+1$ の解を求める増分解析を行う。 
但し式 (15)-a が変位の非線形方程式であるため反復計 算によって解く必要がある。また増分解析における反 復計算の 2 次収束性及び感度解析の精度を保証するた め，連続時間に対する微分形式の構成式 (13)の代りに 時間增分に対する応力積分法と整合する増分型構成則 の微分を用いる必要性が指摘されている(6).(7)。ひずみ 増分 $\Delta \boldsymbol{E}$ を次式のように弾性ひずみ増分 $\Delta \boldsymbol{E}^{e}$ ，塑性 ひずみ増分 $\Delta \boldsymbol{E}^{p}$ ，熱ひずみ增分 $\Delta \boldsymbol{E}^{\prime}$ 及びクリープひ ずみ増分 $\Delta \boldsymbol{E}^{c}$ に分解し,

$$
\Delta E=\Delta E^{e}+\Delta E^{p}+\Delta E^{t}+\Delta E^{c}
$$

と表すと, 弾性構成則テンソル $\boldsymbol{D}^{e}$ を用いて增分 $i+1$ における応力が

$$
\boldsymbol{S}_{i+1}=\boldsymbol{S}_{i}+\boldsymbol{D}^{\epsilon}:\left(\Delta \boldsymbol{E}-\Delta \boldsymbol{E}^{p}-\Delta \boldsymbol{E}^{t}-\Delta \boldsymbol{E}^{c}\right)
$$

と表される。弾塑性解析においては応力積分法と整合 する構成則テンソル $D^{e p^{*}}$ がつぎのように得られる(6)

$$
d\left[\boldsymbol{D}^{e}:\left(\Delta \boldsymbol{E}-\Delta \boldsymbol{E}^{p}\right)\right] \equiv \boldsymbol{D}^{e p p^{*}}: d \boldsymbol{E}_{i+1}
$$

時間増分 $\Delta t$ に対してクリープ則の数值積分を行う場 合は式 (11)，(12) を参照して，クリープひずみ增分を 次式によって求める。但し $0 \leq \theta \leq 1$ である。

$$
\Delta \boldsymbol{E}^{c}=\left.\left[\frac{3 S^{\prime}}{2 \bar{S}} f(\bar{S}, T, t)\right]\right|_{t=t_{t}+\theta \Delta} \cdot \Delta t
$$

これに関連する項の微分は

$$
\begin{aligned}
& d\left(\boldsymbol{D}^{\boldsymbol{e}}: \Delta \boldsymbol{E}^{\boldsymbol{c}}\right)=\boldsymbol{D}^{\boldsymbol{e}}:\left(\frac{\partial \Delta \boldsymbol{E}^{c}}{\partial \boldsymbol{S}_{i+1}}: d \boldsymbol{S}_{i+1}\right) \\
& \equiv \boldsymbol{C}^{\boldsymbol{c}}: d \boldsymbol{S}_{i+1}
\end{aligned}
$$

と表すことができる。ここでは熱が構造解析と独立に 外部から指定される場合を考えるので，温度增分が変 位によらないとして $d \Delta \boldsymbol{E}^{t}=0$ ，また式 (18)，(20)を考 慮すると式 (17)の微分より

$$
\begin{aligned}
& d \boldsymbol{S}_{i+1}=\left(\boldsymbol{I}+\boldsymbol{C}^{c}\right)^{-1}:\left(\boldsymbol{D}^{e p^{*}}: d \boldsymbol{E}_{i+1}\right) \\
& \equiv \boldsymbol{D}^{\boldsymbol{*}:}: d \boldsymbol{E}_{i+1}
\end{aligned}
$$

が得られる。但しクリープひずみに関する時間積分を 陽的に行う場合は $\theta=0, C^{c}=0$ となる。

$B_{N L}^{T}$ を演算子 $\boldsymbol{\eta}(\cdot, \cdot)$ に対応するマトリックスとして， 式 (5) を用いると速度型仮想仕事式 (8) 及び式 (21) の
離散化により接線剛性マトリックスが

$$
\boldsymbol{K}=\sum_{\boldsymbol{e}} \int_{V^{\boldsymbol{r}}} \boldsymbol{B}_{L}^{T} \hat{\boldsymbol{D}}^{* *} \boldsymbol{B}_{L} d V^{e}+\sum_{e} \int_{V^{\prime}} \boldsymbol{B}_{N L}^{T} \hat{\boldsymbol{S}} \boldsymbol{B}_{N L} d V^{e}
$$

と導かれ，次の反復計算により変位増分を求めること ができる。

$$
\begin{aligned}
& \Delta U^{(j)}=K^{(j)-1}\left(F_{i+1}-Q_{i+1}^{(j)}\right) \\
& Q_{i+1}^{(0)}=F_{i}, \quad \Delta U=\sum_{j} \Delta U^{(j)}
\end{aligned}
$$

収束した時点 $\left(\Delta U^{(j)} \approx 0\right)$ で $\Delta U$ は変位増分， $\boldsymbol{K}^{(j)}$ は 平衡状態における接線剛性となる。

2 ・2 感度解析 設計変数からなるべクトルを $b$ ，内力、外力による仮想仕事を $Q 、 \&$ として， 外力が変位によらないと仮定すると，平衡状態におけ る仮想仕事式を次式で表すことができる。

$$
Q(\boldsymbol{u}(\boldsymbol{b}), \boldsymbol{b})=\circlearrowleft f(\boldsymbol{b})
$$

変位 $u$ は設計変数の関数となる。形状を設計変数と する場合は仮想仕事式における積分領域が設計変数に 依存するので，以下に行う微分操作の都合上固定した 参照配置 $\Omega ， \Gamma$ 个物体領域を写像する必要がある。 即ち, 内力及び外力による仮想仕事を

$$
\begin{aligned}
& \bigotimes=\int_{\Omega} S: \delta E J d \Omega \\
& \mho=\int_{\Gamma} \bar{t} \cdot \delta \boldsymbol{u} J d \Gamma+\int_{\Omega} \rho_{0} \boldsymbol{g} \cdot \delta \boldsymbol{u} J d \Omega
\end{aligned}
$$

と表す。但し Jacobian $J$ は設計変数の関数となる。 設計変数に対する全微分を $\tilde{d}$ ，変位及び設計変数 に対する偏微分を $\partial_{u} ， \partial_{b}$ と表記すると次の関係があ る。

$$
\tilde{d}(\cdot)=\partial_{u}(\cdot)+\partial_{b}(\cdot)
$$

従って有限要素解析における増分解析に対応した増分 ステップ $i+1$ での仮想仕事の設計変数に対する微分 は次のようになる。

$$
\begin{aligned}
& \tilde{d} Q_{i+1}=\int_{\Omega} \partial_{u} S_{i+1}: \delta E_{i+1} J d \Omega+\int_{\Omega} S_{i+1}: \partial_{u}\left(\delta E_{i+1}\right) J d \Omega \\
& +\int_{\Omega} \partial_{b}\left(S_{i+1}: \delta E_{i+1} J\right) d \Omega \\
& \tilde{d} \odot f_{i+1}=\int_{\Gamma} \partial_{b}\left(\bar{t}_{i+1} \cdot \delta u J\right) d \Gamma+\int_{\Omega} \partial_{b}\left(\rho_{0} g_{i+1} \cdot \delta u J\right) d \Omega
\end{aligned}
$$


$\partial_{u}(\cdot)$ は設計変数が設計值をとる系，即ち|基本系」に おける変位に対する微分であるため，式 (21)が導かれ た時と同じように，

$$
\partial_{\mu} \boldsymbol{S}_{i+1}=\boldsymbol{D}^{* *}: \partial_{\mu} \boldsymbol{E}_{i+1}
$$

の関係が得られ，さらに式 (4) (6)の関係を使って式 (29) は

$$
\begin{aligned}
& \tilde{d} Q_{i+1}=\int_{\Omega}\left[D^{*}: \boldsymbol{e}_{i+1}\left(\tilde{d} u_{i+1}\right)\right]: \boldsymbol{e}_{i+1}(\delta \boldsymbol{u}) J d \Omega \\
& +\int_{\Omega} \boldsymbol{S}_{i+1}: \boldsymbol{\eta}_{i+1}\left(\boldsymbol{\delta} \boldsymbol{u}, \tilde{d} u_{i+1}\right) J d \Omega \\
& +\int_{\Omega} \partial_{b}\left[\boldsymbol{S}_{i+1}: \boldsymbol{e}_{i+1}(\delta \boldsymbol{u}) J\right] d \Omega
\end{aligned}
$$

となる。式 (30) 及び (32) を離散化すると結局全体節 点変位の感度 $\tilde{d} U_{i+1}$ が次式によって求められる。

$$
\tilde{d} U_{i+1}=\overline{\boldsymbol{K}}^{-1}\left(\tilde{d} \boldsymbol{F}_{i+1}-\partial_{b} \boldsymbol{Q}_{i+1}\right)
$$

ここで,

$$
\begin{aligned}
& \overline{\boldsymbol{K}}=\sum_{e} \int_{\Omega^{e}} \boldsymbol{B}_{L, i+1}^{T} \hat{\boldsymbol{D}}^{* *} \boldsymbol{B}_{L, i+1} J d \Omega^{e} \\
& +\sum_{e} \int_{\Omega^{e}} \boldsymbol{B}_{N L, i+1}^{T} \hat{\boldsymbol{S}}_{i+1} \boldsymbol{B}_{N l, i+1} J d \Omega^{e} \\
& \tilde{d} \boldsymbol{F}_{i+1}=\sum_{e} \int_{\Gamma^{e}} \partial_{b}\left(\boldsymbol{N}^{T} \hat{\boldsymbol{t}}_{i+1} J\right) d \Gamma^{e} \\
& +\sum_{e} \int_{\Omega^{e}} \partial_{b}\left(\boldsymbol{N}^{T} \rho_{0} \hat{\boldsymbol{B}}_{i+1} J\right) d \Omega^{e} \\
& \partial_{b} \boldsymbol{Q}_{i+1}=\sum_{e} \int_{\Omega^{e}} \partial_{b}\left(\boldsymbol{B}_{L, i+1}^{T} \hat{\boldsymbol{S}}_{i+1} J\right) d \Omega^{e}
\end{aligned}
$$

明らかに $\overline{\boldsymbol{K}}$ は有限要素解析における接線剛性と一致 しており，反復計算が収束した時点（平衡状態）での $\boldsymbol{K}^{(j)^{-1}}$ を利用することができる。大規模非線形問題で は反復計算毎に剛性マトリックスの作成及び三角分解 に相当な計算時間を要するが，感度解析の段階ではこ れらの手順を省き，且つ反復計算が収束した時点の情 報のみを利用することにより，式 (33) 右辺括弧内の項 を評価できれば反復計算せずに効率上く感度を求める ことができる。

設計変数に対する外力の微分項 $\tilde{d} \boldsymbol{F}_{i+1}$ は通常既知条 件として与えられる。一方，内力に関する偏微分の展 開は

$$
\partial_{b} \boldsymbol{Q}_{i+1}=\sum_{e} \int_{\Omega^{\prime}} \partial_{b}\left(\boldsymbol{B}_{L, i+1}^{T} J\right) \hat{S}_{i+1} d \Omega^{e}+\sum_{e} \int_{\Omega^{\prime}} \boldsymbol{B}_{L, i+1}^{T} J \partial_{b} \hat{S}_{i+1} d \Omega^{e}
$$

となる。マトリックス $\boldsymbol{B}_{l, i+1}^{r}$ 及び Jacobian $J$ は初期形 状に依存して㧍り，上式右辺第 1 項目は用いる要素夕 イプに対応して微分を求める。形状寸法を設計変数と しない場合この項はなくなる。右辺第 2 項目の評価に は設計变数に対する応力の偏微分を求める必要がある。 本研究では熱条件が温度分布を決定すると考えるため, 温度は一種の設計変数に帰着する。そこで増分ステッ プをクリープ問題における時刻に対応させて，応力は 一般的に次のように表すことができる。

$$
S_{i+1}=S_{i}\left(u_{i}, b\right)+\Delta S\left(u_{i+1}, u_{i}, b\right)
$$

構成則及び応力增分を計算する応力積分アルゴリズム が決まれば上式を厳密に微分することが可能であるが， あらゆる入力条件が設計変数になり得るので，複雑な 形を呈する構成則に対して計算がて長になるほか，異 なる応力積分法または構成則に対して改めて微分の定 式化及びコーディングを行う必要があることは感度解 析の実用化、汎用化の支障となっている。

この問題を解決するため次に示す手法を提案する。 説明を簡潔にするため外力は設計变数に依存しないと する。

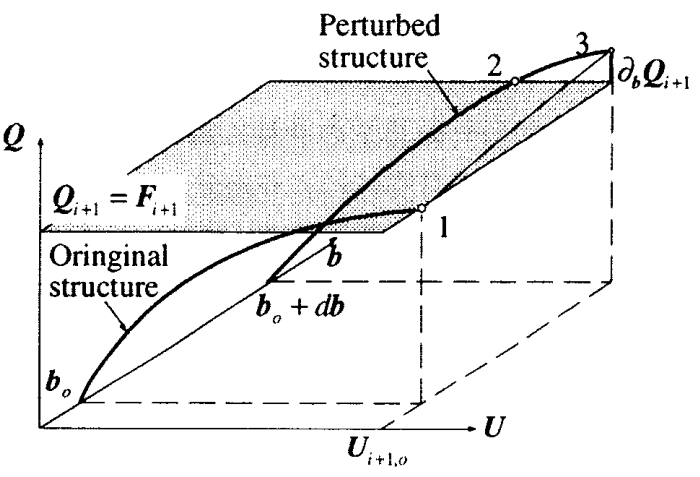

Fig. 1 Variation of structural response with respect to $b$

増分 $i+1$ (時刻 $t_{i+1}$ ) の平衡状態においては変位並びに 応力、内力等の構造挙動が設計变数に依存している。 図 1 のように外力 $\boldsymbol{F}_{i+1}$ に対して設計変数が設計值 $\boldsymbol{b}_{\text {。 }}$ をとる構造系（基本系）の平衡状態を点 1 とする。設 計変数が $\boldsymbol{b}_{o}+d \boldsymbol{b}$ に変わると構造系 (搨動系) の平衡 状態が点 2 に移るが, 掑動系の変位を基本系の変位 $U_{i+1, o}$ に一致させたとすると, 不平衡力を生じて点 3 となる。 $\partial_{b} Q_{i+1}$ がこの不平衡力を表している。以下で は基本系及び摂動系における量を右下添字。及び $p$ を 用いて表記する。設計変数の変化量 一次近似として 


\section{3. 数值解析例}

$$
\left.\partial_{b} \boldsymbol{Q}_{i+1} \approx \frac{\partial \boldsymbol{Q}_{i+1}}{\partial \boldsymbol{b}}\right|_{U=U_{i+1,0}} \cdot \underline{\Delta} \boldsymbol{b} \equiv \underline{\Delta Q_{i+1}}
$$

の関係があるので，内力の偏微分を差分により近似的 に評価することができる。即ち式 (15)-aにより

$$
\begin{gathered}
\text { が得られる。ここで, } \\
\boldsymbol{b}_{p}=\boldsymbol{b}_{o}+\underline{\boldsymbol{b}} \boldsymbol{b} \\
\boldsymbol{U}_{i, p}=\boldsymbol{U}_{i, o}+\tilde{d} \boldsymbol{U}_{i} \\
\hat{\boldsymbol{S}}_{i, p}=\hat{\boldsymbol{S}}_{i, o}+\tilde{d} \hat{\boldsymbol{S}}_{i}
\end{gathered}
$$$$
\Delta \boldsymbol{Q}_{i+1}=\boldsymbol{Q}_{i+1}\left(\boldsymbol{U}_{i+1, o}, \boldsymbol{U}_{i, p}, \boldsymbol{b}_{p}\right)-\boldsymbol{Q}_{i+1}\left(U_{i+1, o}, \boldsymbol{U}_{i, o}, \boldsymbol{b}_{o}\right)
$$$$
=\sum_{e} \int_{\boldsymbol{\Omega}^{*}} \boldsymbol{B}_{L, i+1}^{T}\left(\boldsymbol{U}_{i+1, o}, \boldsymbol{b}_{p}\right) J\left(\boldsymbol{b}_{p}\right)\left[\hat{\boldsymbol{S}}_{i, p}+\Delta \hat{\boldsymbol{S}}\left(\boldsymbol{U}_{i+1, o}, \boldsymbol{U}_{i, p}, \boldsymbol{b}_{p}\right) d \Omega^{e}\right.
$$$$
-\sum_{e} \int_{\Omega^{e}} \boldsymbol{B}_{L, i+1}^{T}\left(\boldsymbol{U}_{i+1, o}, \boldsymbol{b}_{o}\right) J\left(\boldsymbol{b}_{o}\right)\left[\hat{\boldsymbol{S}}_{i, o}+\Delta \hat{\boldsymbol{S}}\left(\boldsymbol{U}_{i+1, o}, \boldsymbol{U}_{i, o}, \boldsymbol{b}_{o}\right) d \Omega^{e}\right.
$$

の定義を使った。 $\tilde{d} U_{i}$ 及び $\tilde{d} \hat{S}_{i}$ は增分 $i$ に扔ける変位 及び応力の感度である。式 (40) 最右辺第 2 項目につい ては有限要素解析における内力計算結果を直接使うこ とができる。右辺第 1 項目については，增分 $i+1 に$ おける設計変数以外の諸量の計算に基本系の変位を用 いるが, 感度の履歷依存性により増分 $i$ における変位 などの感度を考㭸する必要がある。但し，この右辺第 1 項目の評価は形式上有限要素解析の内力計算と全く 同様なので，内力計算ルーチンをそのま々利用するこ とができる。結局, 変位感度が次式によって求められ ることになる。

$$
\tilde{d} U_{i+1} \approx \bar{K}^{-1}\left(\tilde{d} F_{i+1}-\Delta Q_{i+1}\right)
$$

式 (40)の計算に有限要素解析プログラムの内力計算ル ーチンを利用することが可能であるということは，感 度解析の段階においては要素タイプ、構成則及び応力 積分アルゴリズムなどに特別の配慮をすることなく， 既存の有限要素解析コードに整合する感度解析機能を 追加することが容易である，ということを意味する。 但し，式 (33)または (44)の $\overline{\boldsymbol{K}}^{-1}$ は有限要素法に㧍け る簃密な接線剛性の逆行列を表して㧍り、前記の増分 型構成則における応力積分法と整合する接線剛性 (consisitent tangent stiffness) の逆行列を用いる必要があ る。
前節に示した定式化に基づき，著者らが開発した大 変形弾塑性問題の感度解析プログラム“们拡張し, 熱 弾塑性、クリープ問題に適用して数值解析を行った。 但し熱応力及びクリープ現象に対する本手法の有効性 を検証することを主目的として，解析例は微小変形問 題を対象とした。解析には 8 節点 6 面体ソリッド要素 を用い，塑性構成則として Mises 型等方硬化則及び関 連流れ則を仮定した。クリープについては Norton 型 クリープ則を用いた。また設計変数は

$$
b=b_{0}(1+\beta)
$$

と定義し，無次元量 $\beta$ に対する感度を求めた。

3・1 中空円盤の熱弾塑性問题 解析モデルを 図 2 に示す。まず初期温度 $293 \mathrm{~K}$ の中空円板に時刻 $t>0$ 枵内、外面に流体に上る熱伝達条件を与え， 直交する両平面を断熱面として温度分布の時刻歴を熱 解析によって求めた。解析に用いた物性值及び熱条件 を表 1 に示す。設計变数は円盤外面の熱伝達係数と し，沉用コード MARCにより熱解析を行い，差分的 に求めた各積分点の温度感度を用いて本研究で開発し たプログラムにより構造挙動の感度解析を行った。な お円盤の熱膨脹による熱応力解析については解析モデ ルの対称性により 1/8 対称条件を与えた。

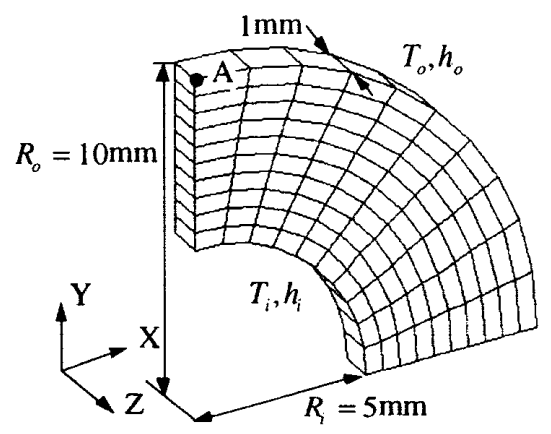

Fig 2 A hollow circle plate under heat convection (1/8 model)

図 2 の $\mathrm{A}$ 点に最も近い積分点における $\mathrm{x}$ 方向応力 成分を外表面の周応力と見なし，A 点における半径方 向変位と共に図 3 に示す。円盤の熱膨脹による半径方 向変位は全時刻を通して增え続けた。一方, 高温流体 による加熱の初期段階で急上昇した円盤外表面付近の 温度勾配 (図 4)により熱㐫力が生じ，加熱から䄪 0.15 秒で円板外表面に最も近い積分点が降伏し始めた。そ して約 0.21 秒で外表面要素全ての積分点が降伏した 後，円盤内部への熱伝導により温度勾配が緩和され， 
降伏した積分点で $0.42 \sim 0.48$ 秒の間に除荷が起こり, その後円盤が弾性状態に戻った。

Table 1 Material properties and heat conditions

\begin{tabular}{|c|c|c|}
\hline $\begin{array}{c}\text { Young's modulus } \\
\mathrm{GPa}\end{array}$ & Poisson's ratio & $\begin{array}{c}\text { Yield stress } \\
\mathrm{GPa}\end{array}$ \\
\hline 196 & 0.3 & 0.735 \\
\hline $\begin{array}{c}\text { Hardening } \\
\text { coefficient } \\
\mathrm{GPa}\end{array}$ & $\begin{array}{c}\text { Coefficient of } \\
\text { thermal expansion } \\
1 / \mathrm{K}\end{array}$ & $\begin{array}{c}\text { Thermal } \\
\text { conductivity } \\
\mathrm{kJ} / \mathrm{mm} \cdot \mathrm{s} \cdot \mathrm{K}\end{array}$ \\
\hline 1.94 & $1.5 \mathrm{e}-5$ & $1.63 \mathrm{e}-5$ \\
\hline $\begin{array}{c}\text { Specific heat } \\
(\mathrm{kJ} / \mathrm{kg} \cdot \mathrm{K})\end{array}$ & $\begin{array}{c}\text { Mass density } \\
\left(\mathrm{kg} / \mathrm{mm}^{3}\right)\end{array}$ & $\begin{array}{c}\text { Film coefficient } \\
\text { for inner surface } \\
\mathrm{kJ} / \mathrm{mm}^{2} \cdot \mathrm{s} \cdot \mathrm{K}\end{array}$ \\
\hline 0.511 & $7.9 \mathrm{e}-6$ & $2.1 \mathrm{e}-6$ \\
\hline $\begin{array}{c}\text { Sink temperature } \\
\text { for inner surface } \\
\mathrm{K}\end{array}$ & $\begin{array}{c}\text { Film coefficient } \\
\text { for outer surface } \\
\mathrm{kJ} / \mathrm{mm}^{2} \cdot \mathrm{s} \cdot \mathrm{K}\end{array}$ & $\begin{array}{c}\text { Sink temperature } \\
\text { for outer surface } \\
\mathrm{K}\end{array}$ \\
\hline 323 & $2.1 \mathrm{e}-5$ & 973 \\
\hline
\end{tabular}

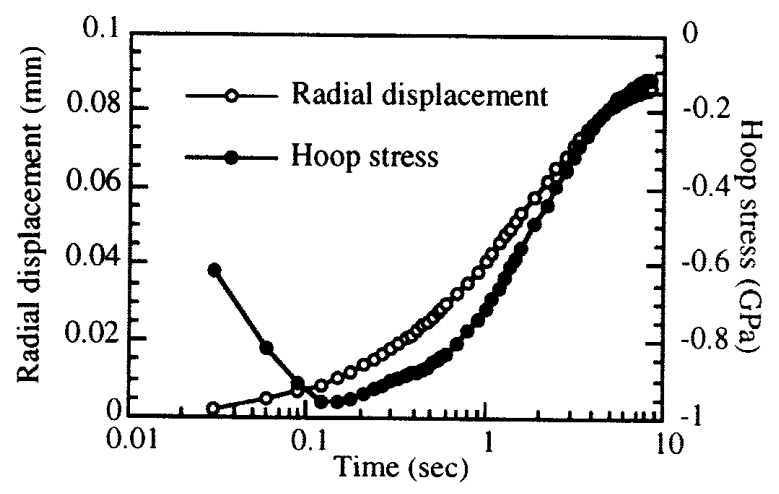

Fig 3 History of radial displacement and hoop stress on outer surface

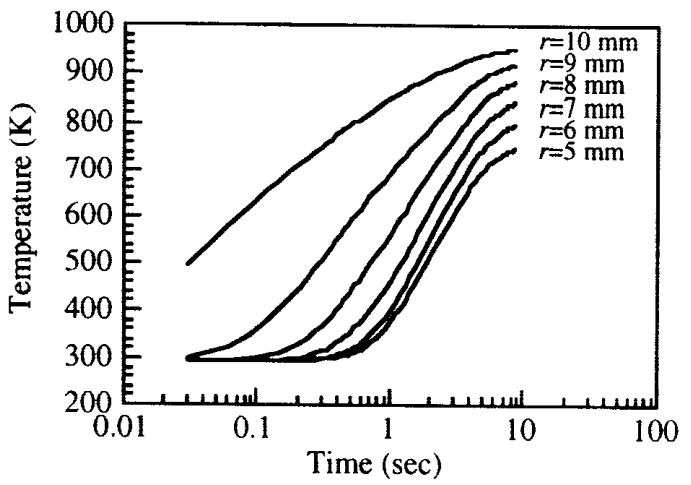

Fig. 4 Temperature history for different radius

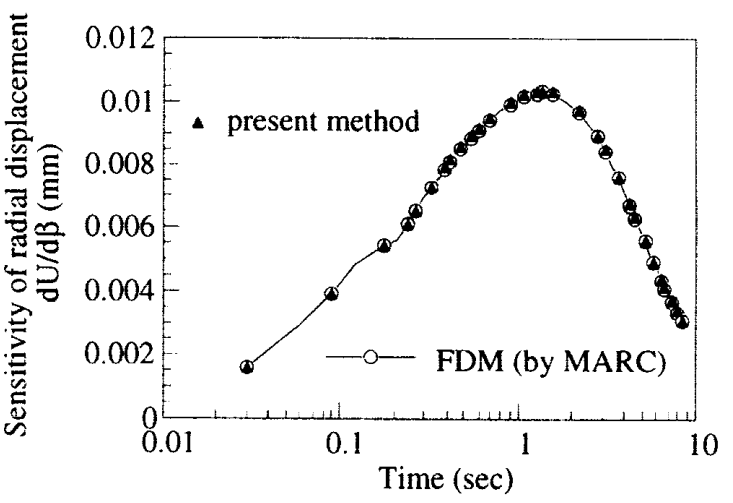

Fig 5 Sensitivity history of radial displacement with respect to film coefficient for outer surface

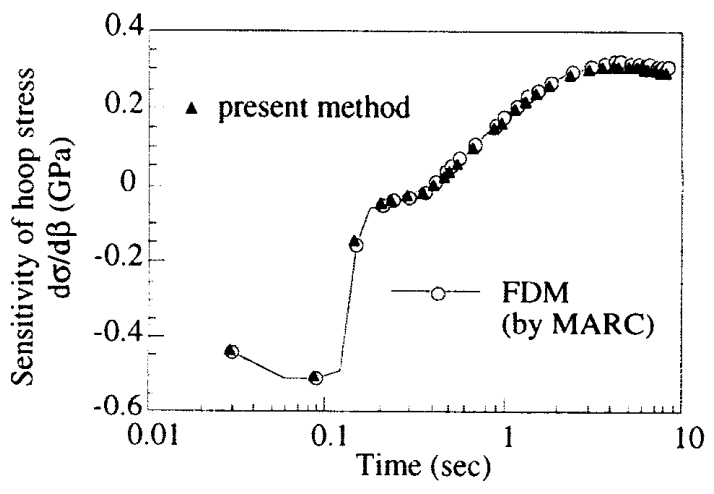

Fig. 6 Sensitivity history of hoop stress with respect to film coefficient for outer surface

次に本手法により感度解析した結果の一部を図 5,6 に示す。四 5 は熱膨脹に対する外表面半径方向変位の 感度履歴であり, 最初は増加したが定常状態に近づく と娍少する傾向に転じた。一方，図 6 に示す外面での 周応力感度の履歴を見ると, 当初負の側に感度が大き くなることから，熱伝達係数の值が大きくなると周応 力も（負の側に）増大することが分かる。しかし降伏 が始まる 0.15 秒付近から熱伝達係数の影響は極めて 小さくなり，逆に 0.42 秒付近から除荷が始まると感 度は正の側に増大し始める。これは熱伝達係数が増加 すると，時間の経過と共に温度勾配が小さくなって行 く際に生じる周方向の圧縮残留応力が逆に小さくなる ことを意味している。なお雨図に示されるように，本 感度解析結果を MARC で差分的に求めた感度と比較 しよく一致することを確認した。

3・2 ボルト締め付け問題 前項で示した解析 に加え，簡単なクリープ問題で感度解析の妥当性を検 証した後，ボルト締め付け問題を解析した。ボルトの 締め付けを模擬した簡易解析モデルを諸条件と共に図 7 に示す。解析は対称性を仮定して全周の1/4につい て行った。Norton 則の係数 $\mathrm{A}$ と指数 $\mathrm{n}$ は応力及び時 間の単位を $\mathrm{kgf} / \mathrm{mm}^{2}$ 及び $\mathrm{hr}$ として与えた。 


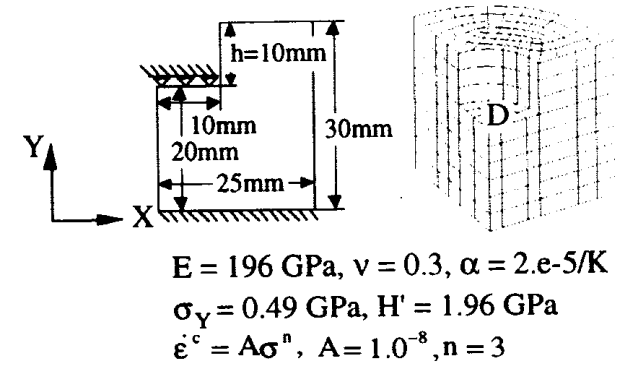

Fig. 7 Simplified model for screw tightening problem ( $1 / 4$ model )

図 7 に示す D 面において Y 方向自由度を拘束し，解 析モデル全体の温度が初期温度 $283 \mathrm{~K}$ から最終温度 573Kまで均一に上昇するとして熱弾塑性解析を行い, その後クリープ解析を実施した。最終温度 $T_{f}$, Norton 則の指数 $\mathrm{n}$ 及び孔の高さ $\mathrm{h}$ を設計変数とし，これらに 対する D 面上の全反力 $\mathrm{F}$ の感度解析結果を図 8 に示 す。図 8 よりNorton 則の指数 $\mathrm{n}$ の感度が最も大きいこ とがわかる。n の増大によるクリープひずみ速度の上 昇が応力楥和を促進し，締め付け力が低下寸ることに なる。比較のため, 汎用コード MARC を使って直接 差分法により求めた $\mathrm{n}$ に対する反力感度も図 8 に併記 してある。

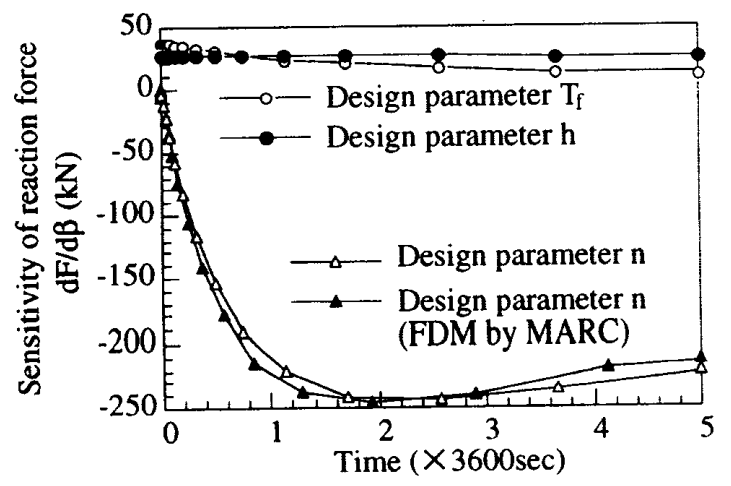

Fig. 8 Sensitivities of reaction force with respect to three design parameters

なお本研究では設計変数の変動に対する内力の変化 を差分的に評価するため，設計変数に撕動量を与える 必要がある。本解析例では摄動量は基準化した $\Delta b / b_{0}$ について 1.0e-4～1.0e-9 の範囲で值を変えても良く一 致した感度が求められた。本手法は摂動量に依存せず, 安定した感度が得られる実用的な手法と言える。

また計算効率については，FEM 解析が約 270 秒 を要するのに対し，一つの設計変数に対する感度解析 時間が約 40 秒であった。設計変数が多数になっても 本手法によれば効率のよい感度解析の行えることが分 かる。

\section{4. 結 言}

本研究では直接微分法に基づく定式化を行い, 設計 変数に対する内力の微分項のみを数値的に評価するこ とにより，熱応力及びクリープ問題に対する感度解析 を簡便かつ効率的に行う手法を提案した。また数值解 析例を通じて本手法の有効性と計算効率を検証した。 本手法は構成則の形式などに依存せず，実用性、汎用 性を持つので，各種非線形問題への適用が可能であり， また既存の FEM 解析コードへの感度解析機能の追加 も容易に行之る。

\section{文献}

(1) 陳, 他 3 名, 機論, 59-567, A(1993), 2742.

(2) 陳, 他 3 名, 機論, 61-589, A(1995), 2100.

（3）矢川元基, 宮崎則幸 有限要素法による熱応力 ・クリープ・熱伝導解析，(1985), サイエンス社.

(4) Kraus, H., Creep Analysis, (1980), John Wiley \& Sons.

(5) Bathe, K.-J., Finite Element Procedures, (1996), Prentice-Hall.

(6) Simo, J. C. and Taylor, R. L., Comput. Methods Appl. Mech. Engrg., 48, (1985), 101.

(7) Vidal, C. A. and Haber, R. B., Comput. Methods Appl. Mech. Engrg., 107, (1993), 393. 